\title{
The Importance of Resilience for Well-Being in Retirement ${ }^{1}$
}

\author{
Cristiane Pimentel Nalin \\ Universidade Salgado de Oliveira, \\ Rio de Janeiro-RJ, Brazil
}

\author{
Lucia Helena de Freitas Pinho França ${ }^{2}$ \\ Universidade Salgado de Oliveira, \\ Rio de Janeiro-RJ, Brazil
}

\begin{abstract}
The increase in the elderly population has prompted research on retirement. This study investigated the importance of resilience, economic satisfaction, the length of retirement, and planning to well-being during retirement of 270 participants. The majority of this sample were men $(64 \%)$, and the mean age was 65 years $(S D=5.7)$. The participants were retired members of 10 public and private organizations in Rio de Janeiro. Factor analysis and hierarchical regression were performed. The results showed that determined resilience (mastery, adaptability, confidence and perseverance) and socioeconomic satisfaction were the main predictors of well-being in retirement and explained $28 \%$ of this model. The findings suggest that well-being in retirement is closely related to socioeconomic satisfaction and determined resilience. Additional research should address the importance of resilience for the well-being of retirees who are or not members of retirement associations. Resilience attitudes should be promoted in Retirement Education Programs.
\end{abstract}

Keywords: resilience (psychology), retirement, subjective well-being

\section{A Importância da Resiliência Para o Bem-Estar na Aposentadoria}

\begin{abstract}
Resumo: O aumento da população idosa incentivou pesquisas sobre a aposentadoria. Esta pesquisa investigou a importância da resiliência, da satisfação socioeconômica, do tempo de aposentadoria e do planejamento para o bem-estar na aposentadoria de 270 participantes. A maioria da amostra foi composta por homens $(64 \%)$, média de idade de 65 anos $(D P=5,7)$, membros de associações de aposentados de 10 organizações públicas e privadas no Rio de Janeiro. Foram efetuadas análise fatorial e regressão hierárquica. Os resultados da regressão revelaram a resiliência determinada - maestria, adaptabilidade, desenvoltura e perseverança - e a satisfação socioeconômica como os principais preditores e explicam $28 \%$ deste modelo. O bem-estar na aposentadoria está relacionado à satisfação socioeconômica e à resiliência determinada. São sugeridas pesquisas comparando aposentados participantes ou não de associações de aposentados e recomendada a promoção de atitudes de resiliência nos programas de preparação para a aposentadoria.
\end{abstract}

Palavras-chave: resiliência (psicologia), aposentadoria, bem-estar subjetivo

\section{La Importancia de la Resiliência Para el Bienestar en la Jubilación}

\begin{abstract}
Resumen: El aumento de la población mayor alentó a una investigación sobre la jubilación. Se investigó la importancia de la resiliencia, la satisfacción socioeconómico, el tiempo de jubilación y la planificación para el bienestar en el retiro de 270 jubilados. La mayoría de la muestra consistió em hombres (64\%). El promedio de edad de los participantes fue de 65 años $(D E=5.7)$, miembros de asociaciones de jubilados de 10 organizaciones públicas y privadas en Río de Janeiro. Se realizaron análisis factorial y de regresión jerárquica. Los resultados de la regresión revelaron que la resiliência decidida - la maestría, la adaptabilidad, el ingenio y la perseverancia - y la satisfacción socioeconómico son los principales predictores y explican el $28 \%$ del modelo. Por lo tanto, el bienestar de la jubilación está estrechamente relacionada com la satisfacción socioeconómico y resiliencia determinada. Se sugieren los estudios que comparan participantes activos o no en las asociaciones de jubilados, y se recomienda la promoción de actitudes de resiliencia en los programas de preparación para la jubilación.
\end{abstract}

Palabras clave: resiliencia (psicologia), jubilación, bienestar subjetivo

The gradual increase in the older, retired population is a relevant topic. In 2013, the numbers of retired people made up $59.1 \%$ of the total Brazilian population (The Brazilian Institute

\footnotetext{
1 Article based in the master's thesis of the first author under the advise of the Professor Lucia França, Ph.D., presented in 2013 to the Graduate Program in Psychology at Universidade Salgado de Oliveira.

Support: Coordination for the Improvement of Higher Education Personnel (CAPES) to the first author and FAPERJ (Rio de Janeiro State Foundation to Support Research) to the second author.

2 Correspondence address:

Lucia Helena de F. P. França. Rua Marechal Deodoro, 217 - bloco A $2^{\circ}$ andar, Centro. CEP 24030-060. Niterói-RJ, Brazil.E-mail: luciafranca@ luciafranca.com
}

of Geography and Statistics [IBGE, acronym in Portuguese], 2013). Demographic changes revealed an increase in the number of retirees and led to a new view for the transition from working to retirement. For this reason, it is important to identify resources for successful retirement during this period.

Humans experience changes starting at birth (Erikson \& Erikson, 1997). Throughout a individual's life, they must overcome possibly uncommon situations, adapt to changes and develop the ability to maintain or improve their well-being because of challenges (Brandão, Mahfoud, \& Gianordoli-Nascimento, 2011; Ryff, Friedman, Morozink, \& Tsenkova, 2012). According to Baltes's (1997) theory 
on selection, optimization and compensation, individuals establish and re-establish their internal and external resources to maximize gains and reduce losses. Such interaction results in successful aging or can help in the adaptation of this process.

During retirement, an individual can achieve such benefits as the opportunity to perform new activities and have more time to devote to their relationships. However, remarkable losses can also occur, such as loss of status, professional identify, and day-to-day life with coworkers, along with financial changes (Taylor, Goldberg, Shore, \& Lipka, 2008; Zanelli, Silva, \& Soares, 2010). Therefore, retirement can be considered an adaptation process in which workers need to deal with transformations in order to achieve well-being (França, 2009).

Through globalization and mergers in organizations, many workers anticipate their retirement. This anticipation can include drastic situations that might compromise the well-being of retirees, mainly if retirement is imposed (França, 2009). However, this period can be an opportunity for great freedom and possibilities for accomplishments in cases where the individual has planned for this phase (França \& Soares, 2009; Rodrigues, 2000; Stepansky, 2012).

Retirement Preparation Programs (RPPs) were implemented in the late 1980s, in most of cases by public organizations, with the aim to provide social support for future retirees (França, Menezes, Bendassolli, \& Macedo, 2013). In general, RPPs aim to support worker in the work-retirement decision and the transition process. They should give workers an opportunity to see ongoing or new opportunities in the labor market (França et al., 2013).

RPPs can encourage social activities with persons who have not yet retired or those recently retired who lacked the opportunity to plan for the future; these programs can also prevent the consequences of not knowing what the retirees will do with their free time during retirement (Stepansky, 2012; Zanelli et al., 2010). For organizations, these programs can enhance work relationships and the organizational environment once other workers who are not experiencing this transition observe the care and respect that the organization has for its employees (França \& Soares, 2009).

Although these programs were recommended in Brazilian legislation (Law no. 8.842, 1994, Law no. 10.741, 2003), their implementation by organizations is still low. However, it is well known that future retirees need to prevent risks during retirement; organizations should encourage financial and health planning and offer opportunities to develop well-being during retirement (Bonsang \& Klein, 2012; França, 2009).

To discuss well-being in retirement, it is necessary to highlight the psychologic definition of well-being. There are two different pathways: the eudaemonic vision (psychological well-being), which is associated with selfaccomplishment of human potential (ability to think, rationalize and apply common sense), and the hedonic view (subjective well-being), which is associated with happiness/pleasure, satisfaction, and spirituality (Ryan \& Deci, 2001). Subjective well-being concerns an individual's self-assessment of his or her own life (Diener, 2009), and its determinants are self-determination and self-direction (Haslam, Whelan, \& Bastian, 2009). In this study we will approach the hedonic well-being perspective.

Oliveira and Torres e Albuquerque (2009) drew attention to feelings of loneliness, lack of information, and financial difficulty during retirement. In this sense, Atchley (1983), Kim and Moen (2002) and Pinquart and Schindler (2007) characterized the first two years of retirement as a "honeymoon" period in which individuals are more satisfied with their lives because of the increase in free time. As the years pass, the well-being index decreases as the individuals face a new routine.

One way to cope with possible adversities in retirement is to reinforce an attitude of resilience. Resilience, which is a concept adopted by psychology from physics, concerns the human ability to positively adapt to and gain strength from adverse situations or risks (Noronha, Cardoso, Moraes, \& Centa, 2009; Poletto \& Koller, 2008; Rutter, 2007).

It is important to note that the resilience concept is still new and complex and that how best to use it is still uncertain. Masten (2011) and Peltz, Moraes and Carlotto (2010) define resilience as the ability of a dynamic system to support or recover from significant challenges that threaten its stability, viability or development. To Ryff et al. (2012), resilience is the ability of individuals to recover and main their well-being when facing adverse situations. Despite these differences in the definition of resilience, it is important to mention that individual and environmental characteristics might vary throughout an individual's life (Rutter, 2007). In addition, it is necessary to analyze two important conditions to identify resilience: the exposure to risk and the positive adaptation to adverse situations despite the risk (Masten, 2014).

Marziali and Donahue (2001) analyzed effects of internal resources in the responses of individuals facing adverse situation during the aging process, such as widowhood and retirement. Results revealed that resilient people who try to understand the meaning of adverse experiences show a high ability to achieve and maintain well-being. França (2009) highlighted that to achieve well-being in retirement the individual should plan for this period far in advance. Planning for retirement should include consideration of economic conditions, collective quality of life, physical and mental health, education throughout life, cognitive stimulus, family and social relationships, personal and social wellbeing and the prospect of a new beginning. According to França (2004), these aspects represent risk and well-being factors for retirement, and individuals who are planning their retirement should consider them in order to obtain the adequate support for adapting to the transition.

Brazil is facing a rapidly aging population, which represents one of the major challenges of this century. 
Retirement can be positive or negative depending on the older workers' attitudes toward this new stage of life and the availability of resources to reinforce positive attitudes (benefits) and to help in facing negative attitudes (losses) (França \& Vaughan, 2008). Therefore, resilience can be considered something that protects and reinforces, for both positive and negative attitudes about retirement. However, few studies have addressed well-being during retirement (França \& Soares, 2009; Oliveira et al., 2009) or the influence of resilience on well-being during retirement.

This study verified the importance of resilience for wellbeing in retirement, as well as the influence of socioeconomic satisfaction, length of retirement, and planning about wellbeing during this period. We also attempted to answer the following question: does resilience contribute positively to well-being in retirement?

We created four hypotheses that are discussed in studies about retirement and resilience but that did not directly address the contribution of resilience for wellbeing in retirement.

Hypothesis 1 - People with a more resilient attitude show a greater ability to achieve and maintain well-being (Marziali \& Donahue, 2001; Resende et al., 2010). On the basis of previous studies, this hypothesis suggests that the higher the resilience index, the greater the perception of well-being.

Hypothesis 2 - Atchley (1983), Kim and Moen (2002) and Pinquart and Schindler (2007) labeled as the "honeymoon" period the first two years of retirement, during which the index for satisfaction with life is higher than in years past. In this sense, this hypothesis presupposes that the shorter the retirement time the greater the perception of wellbeing perception.

Hypothesis 3 - França (2009), Oliveira et al. (2009) and Zanelli et al. (2010) highlight the importance of planning in promotion of well-being during retirement. Therefore, this hypothesis presupposes that respondents who have planned for retirement will show a high well-being index.

Hypothesis 4 - Well-being is influenced by several areas of life: economical, social, family, and others (Diener, 2009; França, 2009). In this sense, this hypothesis presupposes that the greater the socioeconomic satisfaction the greater the well-being during retirement.

\section{Method}

This study used a quantitative and exploratory approach. We administered a survey to obtain empiric data in order to prove or disprove the study hypotheses. These hypotheses are possible answers to the problem of this study (Marconi \& Lakatos, 2007).

\section{Participants}

We invited 1,700 retirees to participate in this study. A total of 270 individuals agreed to participate, representing a response rate of roughly $16 \%$. To be included, participants had to be retired, to participate in a retirement association in Rio de Janeiro, and to not be working at the time of the study. These retirees had worked in 10 large public institutions (58\%) and private organizations (42\%) in Rio de Janeiro. Male participants made up $64 \%$ of the study sample and women, $36 \%$. Ages ranged from 48 years to 78 years $(M=65 ; S D=5.7)$.

Rates of education completion were as follows: completed high school, 44.8\%; completed college, 33.7\%; and completed basic education, $21.1 \%$. The mean family income was R $\$ 5,191.34$. When individuals were asked about their socioeconomic satisfaction, less than half (43.6\%) reported dissatisfaction; thus, level of happiness did not achieve an absolute majority.

Length of retirement ranged from 1 to 20 years $(M=12,4 ; S D=5.3)$. In relation to planning for retirement, $36 \%$ admitted that had done some type of planning for this phase and $13 \%$ affirmed that they were participating in a PPA. It is important to note that PPAs can present different characteristics regarding method used; each organization conducts its programs according to its needs, resources and possibilities. Hence, a PPA was considered a form of psychological support provided by the organization to the worker during the transition from work to retirement, independently of how they achieved retirement.

\section{Instruments}

We used a questionnaire that elicited sociodemographic information: age, sex, educational level, marital status, length of retirement (number of years), whether the retirement was planned or not, and socioeconomic satisfaction. The latter was measured in single question with responses ranging from $1=$ very dissatisfied to $5=$ very satisfied.

Resilience Scale (Wagnild \& Young, 1993). To measure retirees' level of resilience, we used a scale composed of 25 items on a Likert scale of 7 responses $(1=$ totally disagree; $7=$ totally agree). The instrument was validated by Pesce and Assis (2005) in a sample of 810 older individuals aged 53 to 91 years. The scale had a reliability coefficient of .91 , and the mean score was $5.7(S D=0.6)$. Factorial analysis grouped 25 items into two parts: personal competency (17 items) and acceptance of self and life (eight items), totaling $44 \%$ of explained variance.

Subjective Well-Being Scale (Cardoso \& Ferreira, 2009). This instrument measured subjective well-being, with adaptation of the Satisfaction with Life Scale by Lawton (1975) and Neugarten, Havighurste Tobin (1961) and the Positive and Negative Affect Schedule (PANAS) by Watson, Clark and Tellegen (1988). Cardoso and Ferreira's study (2009) included 256 older individuals of both sexes aged $60-87$ years using a 28 -item instrument on a Likert scale of five points, ranging from totally disagree (1) to totally agree (5). Satisfaction with life scale (12 items) presented a reliability coefficient of 
.76 and an explained variance of $12 \%$. For the negative affects version of PANAS (nine items), the reliability coefficient was .79 and the explained variance was $16.2 \%$. For the positive affects version of PANAS (seven items), the reliability was .70 and explained variance was $8.5 \%$ (Cardoso \& Ferreira, 2009).

\section{Procedure}

Data collection. On a day and time scheduled with each retirement association, the questionnaires were distributed collectively, in a single data collection session per association; in this way, all participants received the same guidance by the same adviser. All participants were organized in rooms and completed the questionnaire within 25 minutes on average.

Data analysis. Data were entered into SPSS software version 19. Factorial analysis of scales was done and correlations between resilience variables were analyzed (length of retirement, socioeconomic satisfaction, and subjective well-being). Hierarchical linear multiple regression was also performed (Hair, Black, Babin, Anderson, $\&$ Tathan, 2009) to verify the predictive power of resilience and its factors (determined resilience and resilience about subjective well-being for retirees).

\section{Ethical Considerations}

This study complied with ethical requirements for research in humans. The Ethical and Research Committee of the da Universidade Salgado de Oliveira (Protocol no. $035 / 12$ ) approved the study.

\section{Results}

\section{Resilience Scale}

Resilience scale presented a Kaiser-Meyer-Olkin value equal to .75 and significant result on Bartlett's test of sphericity $\left(\chi^{2}=3027.73 ; p<.001\right)$. According to criteria used by Wagnild and Young (1993), we removed factors that explained less than $5 \%$ of variance, items that had factorial loads less than $.40(9 ; 11 ; 12 ; 20 ; 22 ; 23 ; 25)$, and item 2 , which presented a factorial load higher than .40 in two factors at the same time (Hair et al., 2009). As a result, the final result was composed by 17 items. For this reason, another factorial analysis was done that included 17 items. The reliability coefficient was .85 , with a mean score of $5.6(S D=0.72)$; the total explained variance was $41.2 \%$ by oblimin rotation. The new distribution of items required us to rename factors: determined resilience and individual resilience.

The determined resilience factor expresses the idea of mastery, adaptability, performance and perseverance (Wagnild \& Young, 1993) and composed by 12 items. The explained variance was $29.9 \%$, the eigenvalue was 11.3 , reliability was .83 and mean score was $5.6(S D=0.7)$. The individual resilience factor, which expresses self-sufficiency and independence (Wagnild \& Young, 1993) was grouped into five items. The explained variance was $11.3 \%$, the eigenvalue was 1.9 , reliability was .71 , and mean score was $5.1(S D=0.4)($ Table 1$)$.

\section{Subjective Well-Being Scale}

In our study, the well-being subjective scale had a Kaiser-Meyer-Olkin value equal to .79 and a significant

Table 1

Distribution of Resilience Scale With 17 Items in Two Factors

\begin{tabular}{lcc}
\hline Scale items & Determined resilience & Individual resilience \\
\hline 1. When I make plan, I end up finishing what I planned & $\mathbf{. 5 0}$ & .18 \\
4. To keep interested into something is important to me & $\mathbf{. 6 0}$ & .35 \\
6. I feel proud about myself when I achieved something in my life & $\mathbf{. 6 7}$ & .24 \\
10. I'm determined & $\mathbf{. 1}$ & .14 \\
13. I can handle difficult situation because I've already experienced difficulties before & $\mathbf{4 7}$ \\
14. I'm organized & $\mathbf{. 5 8}$ \\
15. I keep interested in things & $\mathbf{. 7 3}$ & .10 \\
16. In general, I found a reason to laugh at & $\mathbf{. 5 4}$ \\
18. In an emergency situation, people can count on me & $\mathbf{. 6 2}$ \\
19. I usually look at situations in several ways & $\mathbf{. 5 3}$ \\
21. I have a purpose in my life & $\mathbf{. 5 4}$ \\
24. I've got enough energy to do what I've got to do & $\mathbf{. 5 6}$ \\
3. I'm able to prevent myself againts me more than any others & .03 \\
5. I do things by myself I have to & .24 \\
7. I used to accept things without excessive worry & .01 \\
8. I'm my own friend & .07 \\
17. My belief in myself helps me endure difficult times & .09 \\
\hline
\end{tabular}

Note. Factorial loads $>.40$ are in bold. 
result on Bartlett's test of sphericity $\left(\chi^{2}=2302,50 ; p<.001\right)$. Factors that explain less than $5 \%$ of variance were discarded, as suggested by Hair et al. (2009). Therefore, the scale had three factors; the explained variance was $58 \%$ by oblique rotation, the reliability coefficient was .87 , and the mean score was $3.7(S D=0.57)$.

The factor for satisfaction with life, composed by 12 items, had an explained variance of $26 \%$, an eigenvalue of 7.3, a reliability coefficient of .80 and a mean score of 3.9 $(S D=0.6)$. The negative affect factor was composed by nine items; the explained variance was $21.3 \%$, the eigenvalue was 6 , the reliability coefficient was .90 and the mean score was $3.2(S D=0.4)$. Positive affect factor had seven items, with an explained variance of $10.3 \%$, an eigenvalue of 3 , a reliability coefficient of .84, and mean score of $3.9(S D=0.3)$ (Table 2).

\section{Relationship Among Subjective Well-Being, Resilience and Socioeconomic Factors}

In the interpretation of correlations, we adopted the criteria of Milles and Shevlin (2001): .10 to .29 (low),
.30 to .49 (moderate) and $>.50$ (high). Resilience and socioeconomic satisfaction had moderate correlations, positive and significant, respectively, with subjective wellbeing $(r=.42 ; p<.001$ and $r=.31 ; p<.001)$ and time variable of retirement had low, negative and significant correlation with subjective well-being $(r=-.14 ; p<.001)$, which requires careful interpretation. No correlations between independent and dependent variables had a value greater than .90, showing inexistence of multicolinearity (Table 3).

\section{Hierarchical Linear Multiple Regression}

To verify the predictive power of resilience and its factors for subjective well-being, we conducted a hierarchical regression test with two models. In the first model, we entered four variables: socioeconomic satisfaction, length of retirement, planning for retirement (dummy variable planning for retirement $=0$; did not plan for retirement $=1$ ) and sex (dummy variable - male $=0$; female $=1$ ). These variables were related to subjective well-being in several prior studies (Atchley, 1983; França, 2009; Kim \& Moen, 2002;

Table 2

Distribution of Subjective Well-Being Scale in Three Factors

\begin{tabular}{|c|c|c|c|}
\hline Scale & Satisfaction with life & Negative affects & Positive affects \\
\hline 1. Things are getting worse as I'm getting older & .78 & .28 & .09 \\
\hline 2. I feel alone & .59 & .13 & .12 \\
\hline 3. Sometimes I feel that life is meaningless & .57 & .19 & .03 \\
\hline 4. I'm feeling happy today, such as I felt when I was young & .58 & .20 & .03 \\
\hline 5. I have several things to be sad about & .75 & .02 & .04 \\
\hline 6. When I evaluate my life I feel totally satisfied & .53 & .28 & .15 \\
\hline 7. This is the saddest period of my life & .57 & .13 & .31 \\
\hline 8. My life can be happier than it currently is & .69 & .19 & .01 \\
\hline 9. These are the best years of my life & .50 & .12 & .16 \\
\hline $\begin{array}{l}\text { 10. When I thought about my past life I realize that I have not gotten several } \\
\text { important things that I would like to obtain }\end{array}$ & .62 & .09 & .05 \\
\hline 11. I have been getting more than I expected & .42 & .08 & .02 \\
\hline 12. As I'm getting older, things are getting better than I imagined & .57 & .22 & .17 \\
\hline 13. I feel irritated & -.15 & .75 & .21 \\
\hline 14. I feel sad & -.12 & .67 & .15 \\
\hline 15. I feel upset & .08 & .57 & .12 \\
\hline 16. I feel nervous & .10 & .80 & .25 \\
\hline 17. I feel guilty & .02 & .48 & .15 \\
\hline 18. I feel scared & .09 & .63 & .06 \\
\hline 19. I feel hostile & .22 & .65 & .08 \\
\hline 20. I feel tense & .03 & .69 & .21 \\
\hline 21. I feel intimidated & .03 & .49 & .05 \\
\hline 22. I feel interested & .02 & .06 & .61 \\
\hline 23. I feel excited & -.25 & .03 & .78 \\
\hline 24. I feel inspired & .17 & .14 & .58 \\
\hline 25. I feel safe & .02 & .21 & .45 \\
\hline 26. I'm feeling determined & .16 & .25 & .58 \\
\hline 27. I'm feeling enthusiastic & .11 & .25 & .71 \\
\hline 28. I'm feeling dynamic & .03 & .24 & .68 \\
\hline
\end{tabular}

Note. Factorial loads $>.40$ are in boldface. 
Table 3

Correlations Between Well-Being, Satisfaction With Life, Positive Affects, Global Resilience, Individual Resilience, Length of Retirement and Socioeconomic Satisfaction

\begin{tabular}{|c|c|c|c|c|c|c|c|c|}
\hline Variables & 1 & 2 & 3 & 4 & 5 & 6 & 7 & 8 \\
\hline 1. Well-being & ........ & & & & & & & \\
\hline 2. Satisfaction with life & $.782^{* *}$ & ......... & & & & & & \\
\hline 3. Negative affects & $.798^{* *}$ & $.398^{* *}$ & $\ldots \ldots .$. & & & & & \\
\hline 4. Positive affects & $.713^{* * *}$ & $.510^{* *}$ & $.311^{*}$ & ......... & & & & \\
\hline 5. Resilience & $.423^{* * *}$ & $.232^{* *}$ & $.257^{*}$ & $.388^{* * *}$ & $\ldots \ldots \ldots$ & & & \\
\hline 6. Determined resilience & $.389^{* * *}$ & $.312^{* * *}$ & $.254^{* *}$ & $.368^{* * *}$ & $.793^{* *}$ & ......... & & \\
\hline 7. Individual resilience & $.173^{* *}$ & .018 & $.154^{* *}$ & $.256^{*}$ & $.740^{* *}$ & $.364^{* * *}$ & ........ & \\
\hline 8. Length of retirement & $-.135^{* *}$ & -.020 & .067 & $-.186^{* *}$ & -.033 & .002 & -.073 & ......... \\
\hline 9. Socioeconomic satisfaction & $.312^{* * *}$ & $.300^{* * *}$ & .032 & $.244^{* * * *}$ & .012 & .077 & -.089 & .055 \\
\hline
\end{tabular}

$* p<.05 . * * p<.01 . * * * p<.00$.

Oliveira et al., 2009; Pinquart \& Schindler, 2007; Zanelli et al., 2010). In a second model, in addition to the variables in the first model, the determined resilience variable and individual resilience (factors of resilience factors) were added to the equation.

The first model was significant; it explained 5\% of subjective well-being $\left(R^{2} \Delta=.05 ; F(3,236)=14.47\right.$; $p<.001)$. However, socioeconomic satisfaction was the one variable to achieve statistical significance $(\beta=.23$; $t=3.8 ; p<.001$ ). The inclusion of determined resilience and individual resilience variables in the equation represented an increase of $28 \%$ of the explained variance $\left(R^{2} \Delta=.28\right.$; $F(80,452)=450.79 ; p<.001)$. In the second model, the determined resilience factor is highlighted as the variable that better predicts well-being during retirement $(\beta=.37$; $t=6.76 ; p<.001$ ), followed by socioeconomic satisfaction $(\beta=.20 ; t=3.58 ; p<.001)$ (Table 4$)$. Therefore, the greater the determined resilience (determination, mastery, articulation and perseverance) and the greater the socioeconomic satisfaction, the greater the well-being during retirement.

\section{Planning for Retirement}

A $t$ test revealed a significant difference $(t=2.7$; $p<.001)$ concerning the perception of well-being in function of planning for retirement. Participants who affirm that they have planned for retirement present a high index of well-being: planned: $n=97 ; M=4.2(S D=0.54)$; not planned: $n=284 ; M=3.7(S D=0.61)$.

\section{Discussion}

In this study we investigated the aspects that can interfere in the perception of well-being. The correlation between variables and well-being in retirement revealed that the greater the resilience, socioeconomic satisfaction and length of retirement, the greater the perception of well-being during retirement. However, in hierarchical regression, only determined resilience (actions that expressed mastery, adaptability, articulation and perception in problem resolution) and socioeconomic satisfaction were predictors of subjective well-being in retirement.

Table 4

Hierarchical Regression of Model 1 of the Study

\begin{tabular}{|c|c|c|c|c|c|}
\hline Variables & $R^{2} \Delta$ & $F$ & $\beta$ & $t$ & $p$ \\
\hline \multicolumn{6}{|l|}{ Model 1} \\
\hline Length of retirement & .05 & 14.47 & .09 & .54 & .395 \\
\hline Planning for retirement & & & .11 & 1.83 & .067 \\
\hline Socioeconomic satisfaction & & & .23 & 3.80 & $.001 * * *$ \\
\hline Sex & & & .03 & .53 & .597 \\
\hline \multicolumn{6}{|l|}{ Model 2} \\
\hline Length of retirement & .28 & 45.79 & .11 & 1.52 & .348 \\
\hline Planning for retirement & & & .09 & 1.64 & .102 \\
\hline Socioeconomic satisfaction & & & .20 & 3.58 & $.001 * * *$ \\
\hline Sex & & & .09 & 1.71 & .102 \\
\hline Determined resilience & & & .37 & 6.76 & $.001 * * *$ \\
\hline Individual resilience & & & .06 & 1.07 & .108 \\
\hline
\end{tabular}

$* * * p<.001$. 
Hypothesis 1 suggests that the greater the resilience index the greater the perception of well-being. Hierarchical regression revealed determined resilience as the principal predicting well-being. This result corroborates the studies of Dell'Aglio, Koller e Yunes (2006) and Donahue (2001), which showed the importance of resilience indicators in life planning, such as firm acceptance of reality, beliefs, supported by values, strongly supporting that life is meaningful, and the ability to improvise.

Brandão et al. (2011), Peltz et al. (2010) and Ryff et al. (2012) emphasize the importance of resilience in resolving difficult situations. Haslamet al. (2009) highlighted that self-determination and self-guidance are the determinant aspects for subjective well-being. Such results agree with findings of the present study: that actions that express mastery, adaptability, articulation and perception in resolution of problems contribute to well-being in retirement. Therefore, it became clear that well-being in retirement is positively influenced by resilience.

Hypothesis 2 suggested that as the shorter the retirement the greater the perception of well-being. The results revealed a negative and significant correlation between retirement length and well-being, indicating that the beginning of retirement for these participants was harder than those of the their present days, although this showed a low-magnitude correlation $(r=-.14, p<.001)$. In hierarchical regression this hypothesis was not confirmed. Because it concerns themes addressed even less in the scientific literature than resilience and well-being in retirement, further studies need to be done to confirm the correlation of retirement length and well-being, added the comparison between the retirees who frequent or not the associations.

Hypothesis 3 suggested that planning for retirement would positively influence well-being. In the present study, participants who affirmed that they have planned for retirement presented a high index of well-being. These data corroborate the study of Kim and Moen (2002), who argued that workers who planned for retirement had lower levels of anxiety, better adjustment and greater satisfaction. Other corroborating studies are those by França (2009), Oliveira et al. (2009) and Zanelli et al. (2010). Those studies highlight the importance of planning for retirement as a facilitator for well-being. Hence, these results reinforce the need for organizations to encourage planning for retirement.

Hypothesis 4 suggested that the greater the socioeconomic satisfaction the greater the well-being during retirement. Despite this fact, Diener (2009) mentioned that socioeconomic aspects have little power of explanation about well-being. In our study, the hierarchical regression revealed that socioeconomic satisfaction was associated with well-being during retirement. This result agrees with studies by França (2009) and Pinquart and Schindler (2007), who indicated financial planning for retirement as an important strategy to achieve well-being in this phase.
Few studies have evaluated well-being in retirement, and most of the previous studies included non-retired individuals (França \& Vaughan, 2008; Kim \& Moen, 2002). A plausible explanation for this lack is the difficulty contacting employees after they have left their position at companies (França, 2009). In this sense, this study is relevant, because review of databases such as PsycINFO, SciELO and PePSIC finds no studies on the association between resilience and well-being during retirement.

Our study results emphasize that well-being during retirement is closely related to socioeconomic satisfaction and personal competencies (determined resilience). However, considering that our sample was composed of retirees who were not part of retirement associations, a remaining question is whether resilience as a marker for well-being during retirement would also be found among participants who were not part of such communities; the latter group would not participate in lectures offered by associations (lectures about well-being, monthly meetings and end-of-the-year party). Therefore, a limitation of our study was that the findings cannot be extrapolated to that group of retirees. We could not observe possible differences between the two groups in relation to planning and well-being during retirement. Further studies are warranted to confirm the relevance of social support that such associations provide to retirees.

This study revealed that most retirees did not plan their retirement. This lack of planning can be overcome by RPPs, although few companies in Brazil have such programs, despite the legislation that requires them (França et al., 2012). Therefore, the reduced number of respondents who participated in RPPs did not enable us to evaluate the influence of these programs in the well-being of retirees. Future research should be done about the relevance of RPPs as a factor to promote well-being among retirees.

Finally, we recommend that resilience attitudes should be reinforced in RPPs within organizations when future retirees realize the possible losses and gains that they will face. To encourage incorporation discussion of resilience attitudes in RPPs, focus groups could be created. These groups would include future retirees, for whom positive attitudes in the face of the transition from work to retirement would be reinforced. Negative attitudes would be discussed and reassessed in such a way to allow the participants to overcome the impact of losses; such discussion would also allow room for confrontation of negative attitudes, problemsolving, and seeking of new possibilities.

\section{References}

Atchley, R. C. (1983). Age: Continuity and change. Belmont, CA: Wadsworth.

Baltes, P. B. (1997). On the incomplete architecture of human ontogeny: Selection optimization, and compensation as foundation of developmental theory. American Psychologist, 52(4), 366-380. doi:10.1037/0003-066X.52.4.366 
Brandão, J. M., Mahfoud, M., \& Gianordoli-Nascimento, I. F. (2011).Aconstruçãodoconceitoderesiliênciaempsicologia: Discutindo as origens. Paidéia (Ribeirão Preto), 21(49), 263-271. doi:10.1590/S0103-863X2011000200014

Bonsang, E., \& Klein, T. J. (2012). Retirement and subjective well-being. Journal of Economic Behavior \& Organization, 83(3), 311-329. doi:10.1016/j.jebo.2012.06.002

Cardoso, M. C. S., \& Ferreira, M. C. (2009). Envolvimento religioso e bem-estar subjetivo em idosos. Psicologia: Ciência e Profissão, 29(2), 380-393. doi:10.1590/S1414-98932009000200013

Dell'Aglio, D. D., Koller, S. H., \& Yunes, M. A. M. (2006). Resiliencia e psicologia positiva: Interfaces do risco à proteção. São Paulo, SP: Casa do Psicólogo.

Diener, E. (2009). Positive psychology: Past, present, and future. In C. R. Snyder \& S. J. Lopez (Eds.), Oxford handbook of positive psychology (2nd ed., pp. 7-11). New York, NY: Oxford University Press.

Erikson, E. H., \& Erikson, J. M. (1997). The life cycle completed: A review [Extended version]. New York, NY: W. W. Norton.

França, L. H. F. P. (2009). Influências sociais nas atitudes dos 'top' executivos em face da aposentadoria: Um estudo transcultural. Revista de Administração Contemporânea, 13(1), 17-35. doi:10.1590/S1415-65552009000100003

França, L. H.F.P., Menezes, G. S., Bendassolli, P., \& Macedo, L. S. S. (2013). Aposentar-se ou continuar trabalhando? O que influencia essa decisão? Psicologia: Ciência e Profissão, 33(3), 548-563. doi:10.1590/S1414-98932013000300004

França, L. H. F. P., \& Soares, D. H. P. (2009). Preparação para a aposentadoria como parte da educação ao longo da vida. Psicologia: Ciência e Profissão, 29(4), 738-751. doi:10.1590/S1414-98932009000400007

França, L. H. F. P., \& Vaughan, G. (2008). Ganhos e perdas: Atitudes dos executivos brasileiros e neozelandeses frente à aposentadoria. Psicologia em Estudo, 13(2), 207-216. doi:10.1590/S1413-73722008000200002

Haslam, N., Whelan, J., \& Bastian, B. (2009). Big five traits mediate associations between values and subjective well-being. Personality and Individual Differences, 46(1), 40-42. doi:10.1016/j.paid.2008.09.001

Hair, J. F., Jr., Black, W. C., Babin, B. J., Anderson, R. E., \& Tatham, R. L. (2009). Análise multivariada de dados (A. S. Sant'Anna, Trans., 6th ed.). Porto Alegre, RS: Bookman.

Instituto Brasileiro de Geografia e Estatística. (2013). Sintese dos indicadores sociais: Uma análise das condições de vida da população brasileira. Rio de Janeiro, RJ: IBGE. Retrieved from http://biblioteca.ibge.gov.br/visualizacao/ livros/liv66777.pdf

Kim, J. E., \& Moen, P. (2002). Retirement transitions, gender, and psychological well-being: A life-course, ecological model. Journals of Gerontology. Series B, Psychological Sciences ans Social Sciences,57B(3), 212-222. doi:10.1093/geronb/57.3.P212
Lawton, M. P. (1975). The Philadelphia Geriatric Center Morale Scale: A revision. Journal of Gerontology, 30(1), 85-89. doi:10.1093/geronj/30.1.85

Lei No. 8.842, de 4 de janeiro de 1994. (1994, 5 de janeiro). Dispõe sobre a Política Nacional do Idoso, cria o Conselho Nacional do Idoso e dá outras providências. Diário Oficial da União, seção 1.

Lei No. 10.741, de 1 de outubro de 2003. (2003, 3 de outubro). Dispõe sobre o Estatuto do Idoso e dá outras providências. Diário Oficial da União, seção 1.

Marconi, M. A., \& Lakatos, E. M. (2007). Metodologia cientifica: Ciência e conhecimento científico, métodos cientificos, teoria, hipóteses e variáveis, metodologia jurídica (5th ed.). São Paulo, SP: Atlas.

Marziali, E., \& Donahue, P. (2001). Resilience indicators of post retirement well-being (SEDAP Research Paper No. 49). Hamilton, Canada: McMaster University. Retrieved from http://socserv.mcmaster.ca/sedap/p/sedap49.pdf

Masten, A. S. (2011). Resilience in children threatened by extreme adversity: Frameworks for research, practice, and translational synergy. Development and Psychopathology, 23(2), 493-506. doi:10.1017/S0954579411000198

Masten, A. S. (2014). Ordinary magic: Resilience in development. New York, NY: Guilford.

Miles, J., \& Shevlin, M. (2001). Applying regression and correlation: A guide for students and researchers. London, United Kingdom: Sage.

Neugarten, B. L., Havighurst, R. J., \& Tobin, S. S. (1961). The measurement of life satisfaction. Journal of Gerontology, 16(2), 134-143. doi:10.1093/geronj/16.2.134

Noronha, M. G. R. C. S., Cardoso, P. S., Moraes, T. N. P., \& Centa, M. L. (2009). Resiliência: Nova perspectiva na promoção da saúde da família? Ciência \& Saúde Coletiva, 14(2), 497-506. doi:10.1590/S1413-81232009000200018

Oliveira, C., Torres, A. R. R., \& Albuquerque, E. S. (2009). Análise do bem-estar psicossocial de aposentados de Goiânia. Psicologia em Estudo, 14(4), 749-757. doi:10.1590/S1413-73722009000400015

Peltz, L., Moraes, M. G., \& Carlotto, M. S. (2010). Resiliência em estudantes do ensino médio. Psicologia Escolar e Educacional, 14(1), 87-94. doi:10.1590/S1413-85572010000100010

Pesce, R. P., Assis, S. G., Avanci, J. Q., Santos, N.C., Malaquias, J. V., \& Carvalhaes, R. (2005). Adaptação transcultural, confiabilidade e validade da escala de resiliência. Cadernos de Saúde Pública, 21(2), 436-448. doi:10.1590/S0102-311X2005000200010

Pinquart, M., \& Schindler, I. (2007). Changes of life satisfaction in the transition to retirement: A latentclass approach. Psychology and Aging, 22(3), 442-455. doi:10.1037/0882-7974.22.3.442

Poletto, M., \& Koller, S. H. (2008). Contextos ecológicos: Promotores de resiliência, fatores de risco e de proteção. Estudos de Psicologia (Campinas), 25(3), 405-416. doi:10.1590/S0103-166X2008000300009 
Resende, M. C., Ferreira, A. A., Naves, G. G., Arantes, F. M. S., Roldão, D. F. M., Sousa, K. G., \& Abreu, S. A. M. (2010). Envelhecer atuando: Bem-estar subjetivo, apoio social e resiliência em participantes de grupo de teatro. Fractal: Revista de Psicologia,22(3), 591-608. doi:10.1590/S1984-02922010000900010

Ryan, R. M., \& Deci, E. L. (2001). On happiness and human potentials: A review of research on hedonic and eudaimonic well-being. Annual Review of Psychology, 52, 141-166. doi:10.1146/annurev.psych.52.1.141

Rodrigues, N. C. (2000). Aspectos sociais da aposentadoria. In C. R. Schons\& L. S. Palma (Orgs.), Conversando com Nara Costa Rodrigues: Sobre gerontologia social (pp. 21-25). Passo Fundo, RS: UPF.

Rutter, M. (2007). Resilience, competence, and coping. Child Abuse \& Neglect, 31(3), 205-209. doi:10.1016/j.chiabu.2007.02.001

Ryff, C. D., Friedman, E. M., Morozink, J. A., \& Tsenkova, V. (2012). Psychological resilience in adulthood and later life: Implications for health. Annual Review of Gerontology and Geriatrics, 32(1), 73-92. doi:10.1891/0198-8794.32.73

Stepansky, D. (2012). Trabalho, aposentadoria e cidadania: O real e o imaginário. In L. França \& D. Stepansky(Orgs.), Propostas multidisciplinares para o bem-estar na aposentadoria (pp. 305-330). Rio de Janeiro, RJ: Quartet/FAPERJ.

Taylor, M. A., Goldberg, C., Shore, L. M., \& Lipka, P. (2008). The effects of retirement expectations on post-retirement adjustment: A longitudinal analysis. Journal of Managerial Psychology, 23(4), 458-470. doi:10.1108/02683940810869051

Wagnild, G. M., \& Young, H. M. (1993). Development and psychometric evaluation of resilience scale. Journal of Nursing Measurement, 1(2), 165-178.

Watson, D., Clark, L. A., \& Tellegen, A. (1988). Development and validation of brief measures of positive and negative affect: The PANAS scales. Journal of Personality and Social Psychology, 54(6), 1063-1070. doi:10.1037/0022-3514.54.6.1063

Zanelli, J. C., Silva, N., \& Soares, D. H. P. (2010). Orientação para aposentadoria nas organizações de trabalho: Construção de projetos para o pós-carreira. Porto Alegre, RS: Artmed.

Cristiane Pimentel Nalin has a M.S. in Psychology from Universidade Salgado de Oliveira.

Lucia Helena de Freitas Pinho França is a Professor at Universidade Salgado de Oliveira.

Received: June 4, 2014 1st Revision: Dec. 9, 2014 Approved: Feb. 19, 2015
How to cite this article:

Nalin, C. P., \& França, L. H. F. P. (2015). The importance of resilience for the well-being in retirement. Paidéia (Ribeirão Preto), 25(61), 191-199. doi:10.1590/1982-43272561201507 